\title{
Curriculum Content, Ownership Of Universities, Work Experience And Acquisition Of Employability Skills Among Business Education Graduates Of Universities In Cross River State, Nigeria
}

\author{
David Asuquo Edet
}

Department of Vocational Education, University of Calabar, Nigeria

\begin{abstract}
This paper $\mathrm{x}$-rayed curriculum content, ownership of universities, work experience and acquisition of employability skills among business education graduates of universities in Cross River State, Nigeria. Two formulated research hypotheses guided this study. Literature was reviewed in line with the variables under study. The research design adopted was survey. The population for the study was 987 business education graduates between 2007/2008 and 2014/2015 academic sessions from the University of Calabar (UNICAL) and Cross River University of Technology (CRUTECH). The sample of the study was 200 business education graduates drawn purposively using accidental and snowballing sampling techniques. A validated researcher- made four point scale questionnaire titled 'Curriculum Content, ownership of universities, work experience and Acquisition of Employability Skills Questionnaire (CCOUWEESQ) was used for data collection. The instrument was validated by four research experts. A reliability estimate of .70 to .82 was achieved for the instrument using Cronbach Alpha reliability coefficient after a pilot test. The data obtained from the field was converted into values and analyzed using independent t-test statistical technique. All hypotheses were tested at .05 level of significance. Findings revealed among others that graduates of federal university exposed to business education curriculum content are significantly different from their state university counterparts in their acquisition of employability skills. Based on this, it was recommended that government should accord equal recognition, support and provision (in terms of funding, capacity building and infrastructural spread) to both federal and state universities in a way that obvious preference for one category over the other is not perceived. Doing so may erode the dichotomized feelings of being either in a federal or state university from the minds of the students, and rather fix their focus on quality learning that results in the acquisition of employability skills.

Keywords: Curriculum content, ownership of universities, work experience, business education, graduates, employability skills

*Correspondence to Author:

David Asuquo Edet

Department of Vocational Education, University of Calabar, Nigeria

How to cite this article:

David Asuquo Edet. Curriculum Content, Ownership Of Universities, Work Experience And Acquisition Of Employability Skills Among Business Education Graduates Of Universities In Cross River State, Nigeria. American Journal of Educational Research and Reviews, 2020,5:73.

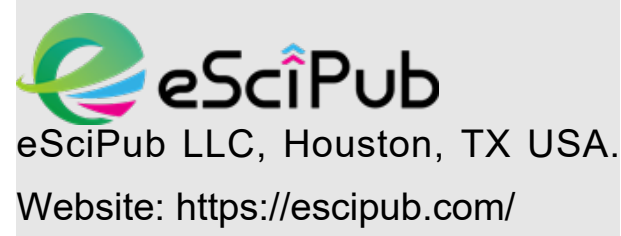




\section{Introduction}

Tertiary institutions particularly the university is believed to be a centre of advanced learning and one of the citadels where in depth education is offered. According to the Federal Republic of Nigeria (FRN, 2004), among the many goals of education at this level is the development of the individual to be self-reliant and useful member of the society through the acquisition of both physical and intellectual skills. These skills when acquired would make learners employable. However, many graduates of Nigerian universities are finding it acutely cumbersome to get work, a situation that has led to pertinacious problem of growing joblessness, and raises query as to whether utilitarian education is really the compelling purpose of universities. This objectionable state of affairs possess huge challenge, and a weighty responsibility on the university as an established institution in that year in, year out there exist an unabated rise in the number of candidates seeking and securing admissions into it with a belief in getting employment after graduation.

Verifiably, universities especially in Nigeria consistently sends out vast chunk of graduates into the job market to either secure employment or provide one. The undeniable truth here is that universities appear to have failed in their well acknowledged mandate of addressing the future of its graduates. The situation that mirrors this is that those skills that recruiters seek in applicants seem barely taught in the universities. Factually, employers of graduates require their recruits to be technically rooted and broadly grounded in their preferred fields because there is a nexus between recruiting a graduate and his or her acquisition of employability skills. These skills can be referred to as employability skills or soft skills. Kathleen (2005) described them as generic skills, and went on to aver that they are not peculiar to any one particular job, but are skills that are required in all industries and jobs from the low cadre to the top management cadre. The Conference Board of Canada (CBC, 2000) calls them the main academic, individual and teamwork skills that employers anticipate from the employees. Omar, Bakar and Rashid (2012) maintained that the necessity of acquiring these skills go beyond getting employment to aiding someone achieve his or her ambition and bringing about meaningful contributions to an entity's strategic pursuits. The acquisition of these skills as Mike (2014) enunciated brings with it numerous benefits including being self- employed, aptness in creating diverse job opportunities, and trimming the society's crime rate index .

conversely, being unable to acquire these skills or poorly acquiring them has over the years label graduates as unemployed, and for those considered to be employed, they are at best underemployed and paid paltry amount vis a vis what they would have rightly earned. The persistent lack of acquiring these skills made Ekpenyong (1988) to brand the universities products as half- baked and un-useful except they are exposed to further training. Dredging to ascertain the cause of this concern, Adebakin, Ajadi and Subair (2015) trail it to a mismatch between the education and training the universities offer and what employers expects. Munishi (2016) fault the ill-competence of universities graduates on the job to poor primary and secondary school training, exacerbated by ineffective curriculum among other factors.

During their sojourn in the university as learners, these graduates were taught, and one of the renowned programs of study is Business Education. In the assertion of Aquah (2014), business education came to public notice and granted relevance status by the FRN in 1977 when the National Policy on Education was introduced. This program of study is poised at equipping the learners with employability skills and knowledge which would motivate them to create, secure, or hold unto the job, and also grow in it. Even though this program of study is run in all educational levels, the intention of the government in offering it is to prepare students for entry level jobs in vocations that do not need post-secondary training (FRN, 2004). If this is true, then 
those who forge ahead to secure university business education training should have an in depth, well-loaded, functional and poised focus of not just becoming employed but employers themselves.

But painful as it is, the program has been running for more than forty years now, yet university graduates of business education inclination are still heavily laden with excruciating unemployment syndrome in spite of the laudable prospects of this promising aspect of education. In the midst of this, universities in Nigeria continue to produce many liberal arts and theoretical business education graduates whose employability potential look blurred. The ones who are employed at all are discovered to be unskilled, clueless, and unable to carry out their assigned duties. The reason for this may not be that there are no jobs, but the lack of employability skills acquisition. It is mind worrying, therefore, to see graduates of a skill laden program like business education among the band wagon of those described as "unemployed" when a well-marshalled program of this nature with options in Accounting, Management, Marketing and Office Technology and Management (OTM) holds employment prospects for her graduates in sectors including but not restricted to; education, financial, industrial, manufacturing, distribution, managerial settings as well as Information and Communication Technology (ICT). In terms of coverage, this paper covers the first three mentioned options except Office Technology and Management (OTM) because the two institutions sampled in this study did not offer it.

Notably, Edet and Udida (2019) undertook a study and reported that the level of employability skills acquisition among universities business education graduates in these options is significantly low. Many factors could be the causation of this lack or poor acquisition of employability skills among graduates of universities. Included in this list of factors may be ownership of the universities. University is an institution of higher learning and research. It is established to award academic degrees and honours in various disciplines. The extant law establishing the university profoundly expects it to offer instructions and guidance on academic programs covering the undergraduate and post graduate studies. In pursuance of this sheer mandate, the universities offer courses of instruction and put in place facilities that aid in the acquisition of knowledge and skills for work and livelihood.

Primarily, the core mission of the university is to promote intellectual inquiry, generate, store and communicate particularized knowledge, sophisticated expertise, as well as high form of culture and ethical bases of conduct (Enahoro \& Badmus, 2013). In his view, Anho (2011) pointed out that university education is central to the cultivation of a knowledge economy and the development of the society at large.

Consequently, it has been closely observed that there exists an unabated burning desire among a vast majority of Nigerians of all ages to acquire university education. This may be premised on the recognition bestowed on the university as a worthy training center capable of raising the intellectual tone of the society, while cultivating the public minds, purifying the national taste, providing the principles of popular aspirations and giving enlargement and sobriety to ideas (Ume in Oladipo, Adeosun \& Oni, 2009). In Nigeria, attempts at classifying the universities have revealed two groupings based on: (1) ownership: existing as federal, state or private institution; and (2) generation: This is tied to the year in which the university was founded. As such, we now have first, second, third, fourth and fifth generation universities (Nwagwu \& Agarin, 2008).

Universities that fall under the first generation category are five led by the establishment of the erstwhile University College, Ibadan now the University of Ibadan in 1948. The twelve second generation universities that were founded between 1970 and 1985 to provide for the manpower need of rebuilding the nation post-civil war, as well as cater for the global desire for industrialization constitute the second generation universities. In the process of time, a need was 
incubated for a paradigm shift in orientation from a broad spectrum university education to a specialized education, and this was the incitement for the setting up of the third generation universities with poised focus on technology and agriculture. This foundational information points to the fact that all the universities set up in these three generations were not only public universities, but federal institutions.

Between 1979 and 1983, the era politically referred to as the second republic, 19 additional universities were set up and were predominantly state universities, to provide for the even spread of educational opportunities for all Nigerians in view of the fact that there was a growing awareness for university education and the existing federal universities as they were could hardly admit all their applicants. This detail provides a brief intro to the fourth generation universities. The granting of licenses to private and mission universities describes the fifth generation universities although a handful of state owned universities were established in this generation too which span from 1999 till date (Nwagwu \& Agarin, 2008).

Today, there are 43 federal universities, 52 state universities and 79 private universities making a total of 174 universities Interestingly, these figures change almost every year in view of the sheer reason that some universities lose their accreditation while some gain accreditation (National Universities Commission NUC, 2020). The focus of this study therefore is on the federal and state universities since the only private university in the study area did not offer business education. Available records disclosed that universities in Nigeria have been churning out quality graduates in their numbers and in different specialties including those from business education extraction (Oladipo, Adeosun \& Oni, 2009). In the words of Daisi (1997), many of the graduates from the nation's universities have found their niche in the academic world in their respective areas of specialization to the enviable extent that some of them are renowned professors, and occupy chairs in the best universities in the world.
This eloquently attests to the resounding truth that employability skills were acquired by them while in the universities.

Regrettably, the situation at hand depicts an academic aberration because of the undesirable quality of graduates churned out of the nation's universities who are barren of soft skills for ready employment. It is not surprising therefore that the erstwhile Executive Secretary of the National Universities Commission (NUC) Professor Peter Okebukola decried the bleak situation when he said that the prime challenge the nation was facing as it concerned the attainment of the desired quality in university education remained the persistent dearth of high quality academic staff. Specifically, he averred that as at 2006, there were a total of 27,394 academic staff in Nigerian university system consisting of $17,836(65 \%)$ in the federal universities; $7,586(28 \%)$ in the state universities and $1,972(7 \%)$ in private universities. Further, he trot out that of these statistics, $5,483(20 \%)$ were Professors/Readers, 6475 $(23.6 \%)$ were senior lecturers, while lecturer 1 comprised 15,436 (56.4\%) (Okebukola, 2006). This glaringly revealed that the best hands in terms of staff mix are found in the federal universities because they employ more than twice the number of academic staff the state universities employ.

This academic staff structure almost meets the NUC Benchmark Academic Standard (BMAS) for business education (NUC, 2007), except that in the lecturer 1 cadre and below, it has exceeded the 45 percent maximum prescribed by BMAS. In relation to the approved staff: student ratio of 1:30, Okebukola (2006) suggested that the Nigerian university system is in dire need of a whooping number of 34,712 academic staff for effective curriculum content delivery such that would lead to the acquisition of employability skills.

Corroborating this pain laden situation, Bamiro (2012) records that paucity of academic staff in the nations universities possess daunting challenge to the quality of program delivery, which translates to lack of acquisition of employability 
skills. Statistically, he articulated that the total enrolment for the various programs and levels in the nation's universities including business education during the 2006/2007 academic session stood at 1,096,312 with the federal universities accounting for 613,935 (56\%) of the enrolment, state universities 405,635 (37\%); and private universities 32, $889(3 \%)$. When compared with the staff strength of 27,934 , this implies a staff: student ratio of 1:40 which is at variance with the regulatory authority's benchmark of 1:30. No wonder the number of unemployed graduates continues to soar because of the overcrowded classroom (Tony, 2014; Folola, Ibidunni, Salau \& Ojo, 2016) which makes the curriculum content delivery less imparting.

Bamiro (2012) revealed further that the lowest ratio of 2:19 is found in the private universities while the highest ratio of 1:59 is found in the state universities. These lurid figures present rather poor staffing levels of the universities, particularly the state universities.

Relatedly, the NUC (2006) issued a report that showed that of the 72,704 staff in the federal universities; only 16,856 representing 23.2 percent were academic staff. Emphatically, the report concluded that most if not all the universities in Nigeria are bottom heavy in terms of academic staff composition. The consequential effect of this is that employability skills seems uncertain to be acquired by the graduates of business education because those who are supposed to be the chief implementers of the curriculum content - the academic staff are leaving the academic world to join the 'rat race' in the commercial world (Oladipo, Adeosun \& Oni, 2009). Ali (2013) opined that many intellectual big wigs are fleeing from the frustration of university life into other wealth spinning and satisfying endeavor even outside the shores of the country. Tony (2014) commented that the intriguing search for innovation that once served as the refining influence of a typical Nigerian university both federal and states had long been eroded, paving way for faculty exodus into other rewarding sectors where commensurate pay and recognition of hard work and excellence are accorded it pride of place among the professionals. Others migrate for political reasons, while some left on economic grounds. The resultant effect is seen in the illequipped graduates of universities who are obsessing over their inability to acquire employability skills when they ought to be brimming with skills for work. These situations have wearied most of them and drain their strength for many years after graduation with the net impact of gallivanting when they were supposed to be the initiator of jobs and employers of labour. This is indeed an acute misfit.

The situation appears gravely distressing when considered against the hitherto encomiums showered on Nigerian universities as the hub of universities in the West African sub-region (Oladipo, Adeosun \& Oni, 2009). This development that revolves round numerous factors including inappropriate curricula (Kayode, 2002) reveals a causal relationship between the curriculum content of a program of study and graduates acquisition of employability skills.

Asuquo and Agboola (2014) quoted Sam Egwu, the former Minister of Education when he spoke at a retreat organized for the newly reconstituted governing council boards for federal universities in Abuja as adducing the precarious situation whereby universities graduates remained unemployed and those employed were underperforming to the non-acquisition of employable skills and the lack of sufficient skills. The former minister stressed further that about 15-30 percent of the teaching aids and infrastructural facilities are non-functional, moribund, and are obsolete with the clearest negative impact on the quality of teaching, learning and research. In his opinion, only 20 percent of graduates from Nigeria universities are employable. This implies that 80 percent of Nigerian graduates including those of business education are without the requisite skill for employment.

Though the end to this is still out of sight, hope is not lost in terms of improving the quality and number of academic personnel required to im- 
plement the curriculum content of business education program, and propel the notion for the acquisition of employability skills into the fiber of universities graduates. Bamiro (2012) in a renaissance of expectation reported that in some federal universities sponsorship and capacity building by foundations such as Mac Authur and TETFUND have seen $538 \mathrm{Ph}$.Ds and 826 masters students who are academic staff trained in local institutions (1157) and overseas institutions (207).

So far, there seem not to be enough empirical investigations that measure the performance of federal and state universities vis-à-vis the curriculum content, but the National Universities Commission ranking of universities in years 2015, 2016 and 2017 shows a fixed position with respect to ranking among federal universities. The list indicates that federal universities were always in the first tenth positions in the three consecutive years. While the best positions occupied by state universities were eleventh, seventeenth and nineteenth in the order of best 3 positions.

At the global level, not even one Nigerian university is graded among the best 2000 universities in the world in both Times High Education- QS ranking, Academic Ranking of World Universities (SJTUR), webometrics ranking, professional ranking of world universities, and Newsweek ranking among others (Folola, Ibidunni, Salau, \& Ojo, 2016). All these are unambiguous testaments that all is not well with the Nigerian universities both federal and state. Therefore, the doggedness of the owners of these universities to cooperate relevantly through the validation of curriculum design and content (Middlehurst, 2001), adherence to carrying capacity (Arikewuyo \& Illusanya 2014); and collaborations and academic linkages (McCauley \& Wakefield, 2006) are plausible avenues to galvanize the graduates into the acquisition of employability skill.

Beside the issue of ownership of university, work experience is yet another contributor to the sub- ject of employability skill acquisition. Work experience is any experience that a person gains while working in a particular area or occupation. It is a far more flexible term, but ordinarily refers to some form of temporary work placement within an entity where an individual works on junior level tasks for the precise aim of gaining experience and insight into the industry (Wikipedia, 2014). The Business Dictionary (2014) sees it as familiarity with a skill or field of knowledge acquired over months or years of actual practice and which presumably results in mastery. Work experience is viewed by Bates (2008) as the participation in productive work in school, office, in the home, in the workshop, on a farm, in a factory, or in any productive endeavour.

Wikipedia (2014) classifies work experience into various types as summer jobs, part-time jobs, work shadowing, industry placements (Sandwich placements) and volunteering. Scholars like Ibrahim and Jaaffar (2017); Jackson (2013); Rowe and Zegwaard (2017) identified fieldwork, internship, cadetships, cooperative education, clinical placement, and work integrated learning as activities that brings about work experience. Jayanthi, Balakrishnan, Ching, Latiff and Nasirudeen (2014) added part-time employment while Omar, Bakar and Rashid (2012) posited that experience gathered while working prior to enrolling at the tertiary institution is termed work experience. The latter is the focus of this study.

Work experience is considered an effective tool that enhances graduates employability (Khalid, Hamid, Sallin, Othman, Awang \& Nur, 2014). Sat, Yusoff and Panatik (2014) maintained that work experience does not only act as a platform for preparing students for jobs and exposing them to real work situations, rather, it further aids in developing key competencies in the students. In this light, a strong alignment was found in the remarks of Billett (2011); Martin, Rees and Edwards (2011) that work experience improve employability outcomes for students in numerous ways. First, through the creation of opportunities that builds students' implicit confidence in pro- 
fessional practice, and the according of appreciable importance to employability skills acquisition. Secondly, the enhancement of skills such as teamwork, professional judgment, communication and problem solving skills are key benefits derivable from the acquisition of work experience by students (Coll, Eames, Paku, Lay, Ayling, Hodges....Martin (2009). Smith, Ferns and Russell (2014) affirmed that work experience possesses the capacity of enhancing graduates work preparedness and development of generic/professional skills, preparing students for transition into the workplace (Chillas, Marks \& Gallaway, 2015; Jackson, Ferns, Rowbottom \& McLaren, 2015), promoting higher earning potential/employment rates (Council of Ontario Universities, 2014, Gault, Leach, Duey, 2010); contribute to career development (Jackson 2015); and help develop professional identity (Jackson, 2016, Trede, 2012).

Fundamentally, it is believed that learning is never a by-product of work, instead learning is cardinal to engaging in work practice (Smith, Meijer\& Kielley -Coleman, 2010). Hence, when graduate with work experience are exposed to a program's curriculum content (like business education), an array of employability skills such as teamwork, communication, self-management, critical thinking and problem solving are acquired (Australian Association of Graduate Employers, 2011; Confederation of British Industry, 2011) among others. As such, their development in undergraduate education, business education inclusive is now considered needful as they allow for the effective application of graduates disciplinary knowledge and skills in the workplace.

One essential significant of work experience to students is that it spurs them to reflect on their individual learning, equip them with a better understanding of the world-of-work, and ways of conducting and managing themselves in different situations (Mcllueen, Brooks, Lichtenberg, Smith, Torjul \& Tyler, 2011), all of which are tonic to graduate acquisition of employability skills. Omar, Bakar and Rashid (2012) studied employ- ability skills acquisition among Malaysian Community College students. The study concluded that although work experience improves student's technical skills, there was no significant difference between students' employability skills and students' work experience.

Conversely, Marjahan and Newman (2009); Orner (2009); McConomy (2010); Munro (2007) and Bennett (2006) claimed that it is crucial for students to gain substantial level of work experience prior to entering the job market. They emphasized the towering role that work experience plays in enhancing students employability skills allied with opportunities for career enhancement.

Paisey and Paisey (2010) conducted a study on developing skills via work placement in accounting, student and employer views. The study which focused on the improvement of skills during a work placement year in a Scottish accounting degree showed that experience garnered through work placement successfully develops an avalanche of transferable personal skills for students. Consequently, Omar, Bakar and Rashid (2012) found this as having important implication for the development of new curricula for community colleges that can ensure that students possess a certain level of employability skills before they venture into the employment market.

In Nigeria, the governments (at both the federal and states levels) as well as private spirited bodies are beaming with relentless desire to operate universities now than ever, and this drive has made many people to seek for university education. Some have had the privilege of being admitted in the universities prior to seeking for employment after graduation, while others had to work first before seeking for admission into the institutions to earn a degree. The questions begging for answer is this: does the acquisition of employability skills hinge on whether someone graduates from a federal or state owned university? Does the acquisition of employability skills depends on ones prior work experience? The 
answer to these poser describes why this study was undertaken.

\section{Purpose of the study}

The main purpose of this study was to investigate curriculum content, ownership of universities, work experience and acquisition of employability skills among business education graduates of universities in Cross River State, Nigeria. Specifically, the study sought to examine:

1. The influence of business education curriculum content on the acquisition of employability skills among graduates of federal and state owned universities.

2. The influence of business education curriculum content on the acquisition of employability skills among graduates of universities based on work experience.

\section{Research hypotheses}

The following hypotheses guided the study:

1) Graduates of federal universities exposed to business education curriculum content are not significantly different from their state universities colleagues in the acquisition of employability skills.

2) Universities graduates with work experience exposed to business education curriculum content are not significantly different from their counterparts without work experience in their acquisition of employability skills.

\section{Methodology}

The study adopted survey research design involving the use of questionnaire. Two research hypotheses guided the study. The study area was Cross River State, one of the states in Nigeria's south-south geo-political zone. The population for the study was 987 business education graduates between 2007/2008 and 2014/2015 academic sessions from UNICAL and CRUTECH. Of this number, 200 was purposively drawn as sample using accidental and snowballing techniques. This is shown in Table 1. A fourpoint scale structured questionnaire validated by four research experts from the two institutions was used to elicit responses from the respondents. The reliability estimate ranging from .70 to .82 was achieved for the instrument using Cronbach Alpha reliability coefficient after a pilot test. The instrument was administered personally by the researcher with the help of three research assistants. This was done after relevant information about the problem being researched was explained to the respondents. Independent t-test was used to test all the hypotheses at .05 level of significance.

TABLE 1 Population sample of the study

\begin{tabular}{lllll}
\hline S/n & Institution & Options & Population & Sample \\
\hline 1 & UNICAL & Accounting & 96 & 20 \\
& & Management & 142 & 29 \\
& & Marketing & 52 & 10 \\
2 & CRUTECH & Accounting & 296 & 61 \\
& & Management & 402 & 82 \\
& & Total & 987 & 200 \\
\hline
\end{tabular}

\section{Results}

Hypothesis one: Graduates of federal universities exposed to business education curriculum content are not significantly different from their state universities colleagues in the acquisition of employability skills.

Test for significance was done using independent t-test at .05 level of significance. A summary of the result is presented in Table 2. 
TABLE 2 Independent t-test analysis of the influence of business education curriculum content on graduates' acquisition of employability skills based on ownership of university

\begin{tabular}{|c|c|c|c|c|c|c|}
\hline Sub-components & Ownership of university & $\mathrm{N}$ & Mean & Std. Dev. & $\mathrm{t}$ & p-level \\
\hline \multirow[t]{2}{*}{ Communication skills } & Federal & 88 & 11.79 & 4.125 & 4.470 & .001 \\
\hline & State & 112 & 13.27 & 5.802 & & \\
\hline \multirow[t]{2}{*}{ Problem-solving skill } & Federal & 88 & 10.61 & 3.315 & 5.861 & .000 \\
\hline & State & 112 & 11.97 & 3.961 & & \\
\hline \multirow[t]{2}{*}{ Numeracy skill } & Federal & 88 & 10.57 & 3.570 & 3.844 & .003 \\
\hline & State & 112 & 11.25 & 4.434 & & \\
\hline \multirow[t]{2}{*}{ Critical thinking skill } & Federal & 88 & 10.48 & 3.798 & 2.281 & .001 \\
\hline & State & 112 & 9.59 & 3.115 & & \\
\hline \multirow[t]{2}{*}{ Teamwork skill } & Federal & 88 & 11.31 & 4.025 & 2.481 & .001 \\
\hline & State & 112 & 10.36 & 3.615 & & \\
\hline \multirow[t]{2}{*}{ Decision making skill } & Federal & 88 & 9.47 & 3.225 & 3.881 & .004 \\
\hline & State & 112 & 10.11 & 3.991 & & \\
\hline \multirow[t]{2}{*}{ IT/computer skill } & Federal & 88 & 11.72 & 4.925 & 2.226 & .002 \\
\hline & State & 112 & 10.66 & 3.619 & & \\
\hline \multirow[t]{2}{*}{ Planning \& organizing skill } & Federal & 88 & 10.57 & 3.133 & 3.594 & .001 \\
\hline & State & 112 & 10.96 & 3.425 & & \\
\hline \multirow[t]{2}{*}{ Continuous learning skill } & Federal & 88 & 10.29 & 4.229 & 2.431 & .000 \\
\hline & State & 112 & 9.44 & 3.315 & & \\
\hline \multirow[t]{2}{*}{ Self-management skill } & Federal & 88 & 10.97 & 3.251 & 2.159 & .000 \\
\hline & State & 112 & 11.86 & 4.344 & & \\
\hline
\end{tabular}

${ }^{*} \mathrm{P}<.05$; critical $\mathrm{t}=1.96$

Table 2 disclosed that the independent t-test analysis of the influence of business education curriculum content on the acquisition of employability skills among graduates of universities with respects to ownership of universities yields significant t-values for all the 10 sub-components of employability skills which were superior to the critical t-value of 1.96 at .05 probability level. Consequently, the null hypothesis which state 
that graduates of federal universities exposed to business education curriculum contents are not significantly different from their state university counterparts in their acquisition of employability skills is rejected. The mean score shows significance in favour of federal university graduates for critical thinking skill, teamwork skill, IT/computer skill and continuous learning skills; while for the state university graduates, the mean score shows significance in favour of communication skill, problem solving skill, numeracy skill, decision making skill, planning and organizing and self-management skill. This means that the state university graduates exposed to business education curriculum contents acquired more employability skills than their federal university counterparts.

Hypothesis two: Universities graduates with work experience exposed to business education curriculum content are not significantly different from their counterparts without work experience in their acquisition of employability skills.

Test for significance was done using independent t-test at .05 level of significance. A summary of the result is presented in Table 3.

Table 3 shows that the independent t-test analysis of the influence of business education curriculum content on the acquisition of employability skills among graduates of universities with regards to work experience yields significant $t$-values for all the 10 sub-components of employability skills which were superior to the critical tvalue of 1.96 at .05 probability level. Therefore, the null hypothesis which says that universities graduates with work experience exposed to business education curriculum content are not significantly different from their counterparts' without work experience in the acquisition of employability skills is rejected. The mean score shows significance in favour of those with work experience for problem solving skill, critical thinking skill, decision making skill and planning and organizing skills, whereas for those without work experience, the direction of significance favoured them in terms of communication skill, numeracy skill, teamwork skill, IT/computer skill, continuous learning skill and self-management skill. The implication of this is that universities graduates without work experience exposed to business education curriculum contents acquired more employability skills than their colleagues with work experience.

\section{Discussion of findings}

Findings with regards to hypothesis one revealed a mean score of graduates from federal university to be higher than those of graduates from state university in terms of critical thinking skill, teamwork skill, IT/computer skill, and continuous learning skill. They graduates may have achieve this feat because of the palpable reason put up by Okebukola (2006) that the majority of academic staff in Nigerian universities are found in the federal universities, and the revelation of Bamiro (2012) that the lecturer: students ratio in federal universities is between the lowest ratio observed in private universities and the highest ratio found in state universities implying that in federal universities, the ratio is close to meeting the benchmark requirement set. This clearly depicts that the moderate lecturer: students ratio in federal universities may have underpinned the graduates' acquisition of employability skills as disclosed in this study.

Similarly, the report of Bamiro (2012) that in some federal universities, sponsorship and capacity building provided by foundations such as Mac Author and TETfund to academic staff of federal universities may have been the pep to graduates of federal universities exposed to business education curriculum content to acquire employability skills. On the other hand, findings of this study disclosed that graduates from the state university exposed to business education curriculum content had mean score higher than their counterparts from the federal university in terms of communication skills, problem solving skills, numeracy skills, decision making skills, planning and organizing skill and selfmanagement skills. This finding is in line with Daisi (1997) who averred that many graduates from the nation's universities have found their niche in the academic world and occupy chairs 
David Asuquo Edet, AJERR, 2020; 5:73

because they had acquired employability skills. findings of this study defend Oladipo, Adeosun The findings also justify the view of Anho (2011) and Oni (2009) that encomiums were showered that university education is central to the cultiva- on Nigerian universities as the hub of universition of a knowledge economy. Furthermore, the ties in the West African sub-region.

TABLE 3 Independent t-test analysis of the influence of business education curriculum content on graduates' acquisition of employability skills based on work experience

\begin{tabular}{|c|c|c|c|c|c|c|}
\hline Sub-components & Work experience & $\mathrm{N}$ & Mean & Std. Dev. & $\mathrm{t}$ & p-level \\
\hline \multirow[t]{2}{*}{ Communication skill } & Acquired & 41 & 12.08 & 4.502 & 2.301 & .002 \\
\hline & Not acquired & 159 & 13.43 & 5.791 & & \\
\hline \multirow[t]{2}{*}{ Problem-solving skill } & Acquired & 41 & 13.58 & 5.651 & 2.370 & .001 \\
\hline & Not acquired & 159 & 12.19 & 4.419 & & \\
\hline \multirow[t]{2}{*}{ Numeracy skill } & Acquired & 41 & 11.55 & 4.176 & 2.954 & .003 \\
\hline & Not acquired & 159 & 13.41 & 5.148 & & \\
\hline \multirow[t]{2}{*}{ Critical thinking skill } & Acquired & 41 & 12.62 & 4.719 & 3.761 & .004 \\
\hline & Not acquired & 159 & 11.98 & 3.615 & & \\
\hline \multirow[t]{2}{*}{ Teamwork skill } & Acquired & 41 & 12.22 & 4.819 & 3.393 & .001 \\
\hline & Not acquired & 159 & 13.61 & 5.149 & & \\
\hline \multirow[t]{2}{*}{ Decision making skill } & Acquired & 41 & 12.28 & 4.177 & 2.605 & .002 \\
\hline & Not acquired & 159 & 11.03 & 2.587 & & \\
\hline \multirow[t]{2}{*}{ IT/computer skill } & Acquired & 41 & 10.61 & 3.516 & 3.519 & .005 \\
\hline & Not acquired & 159 & 11.05 & 4.843 & & \\
\hline \multirow[t]{2}{*}{ Planning \& organizing skill } & Acquired & 41 & 13.47 & 5.156 & 2.173 & .001 \\
\hline & Not acquired & 159 & 12.36 & 4.258 & & \\
\hline \multirow[t]{2}{*}{ Continuous learning skill } & Acquired & 41 & 11.16 & 3.158 & 2.120 & .003 \\
\hline & Not acquired & 159 & 12.05 & 4.645 & & \\
\hline \multirow[t]{2}{*}{ Self-management skill } & Acquired & 41 & 10.61 & 3.570 & 4.727 & .002 \\
\hline & Not acquired & 159 & 11.95 & 4.165 & & \\
\hline
\end{tabular}

${ }^{*} \mathrm{P}<.05 ;$ critical $\mathrm{t}=1.96$

On the contrary, the findings controvert Sam Egwu in Asuquo and Agboola (2014) that 80 percent of Nigerian graduates including those of business education are without the requisite skills for employment. Invariably, employability skills may have been impacted on the graduates https://escipub.com/american-journal-of-educational-research-and-reviews/ of both federal and state universities exposed to business education curriculum contents, but other factors such as "god-fatherism" syndrome in the Nigerian system, inability to access timely advert information, fewer employment opportunities, and unstable investment outcomes may 
have been the bane for their dwindling fortune in securing employment.

The second finding disclosed that universities graduates with work experience exposed to business education curriculum contents are significantly different from their counterparts without work experience in the acquisition of employability skills. This finding is in agreement with Billett (2011); Martin, Rees and Edwards (2011) who quip that work experience improve employability outcomes for students in numerous ways. Furthermore this findings support Khalid, Hamid, Sallin Othman, Awang, and Nur (2014) who posited that work experience is considered as an effective tool that enhances graduates' employability.

Similarly, the affirmation of Smith, Ferns, and Russell (2014) that work experience possesses the capacity of enhancing graduates' work preparedness and development of core/expert skills, as well as preparing students for transition into the work place equally vindicate this finding. This is true because when graduates who are inundated with work experience are exposed to a program's curriculum content like business education, employability skills will be gradually stirred up and built in them over time.

In a more detail description, the findings of the study revealed that universities graduates with work experience exposed to business education curriculum content had a mean score that is higher than their counterparts without work experience in problem solving skill, critical thinking skill, decision making skill, and planning and organizing skills. On the other hand, the direction of significance tilt in favour of those without work experience against those with work experience in communication skill, numeracy skill, teamwork skill, IT/computer skill, continuous learning skill and self- management skills.

This finding rebut Omar, Bakar, and Rashid (2012) who used research evidence to argue that work experience improves students' technical skills rather than employability skills. Supporting this findings, Marjahan, and Neuman (2009); Orner (2009); McConomy (2010); Munro
(2007) and Bennett (2006) justified that it is crucial for students to gain substantial level of work experience prior to entering the job market. More so, the findings of Paisey and Paisey (2010) that work placement greatly gears up an avalanche of transferable skills in students strongly sustains the findings of this study.

\section{Conclusion}

Based on the findings in this study, it was concluded that marked difference exist between business education graduates of federal and state universities in their acquisition of employability skills. Although the extent of gapping was not wide, it is still important for the owners of these universities to deploy all necessary resources towards the development of their institutions so that their graduates will not only be employed in today's competitive world of work, but become employers themselves. More so, significant different was found between business education graduates of universities with work experience and their folks without work experience. Though the difference was not wide, there is still need to integrate the Students Industrial Work Experience Scheme (SIWES) into the curriculum of universities or create similar opportunities where students/graduates will be exposed to the realities in the real world of work in view of the fact that no knowledge (including that gained from work) is a waste.

\section{Recommendations}

Arising from the findings of this study, the following recommendations were advanced:

1) Government should accord equal recognition, support and provision (in terms of funding, capacity building and infrastructural spread) to both federal and state universities in a way that obvious preference for one category over the other is not perceived. Doing so will erode the feelings of being either in a federal or state universities from the minds of the students, and rather fix their focus on quality learning that results in the acquisition of employability skills. 
2) The regulatory authority - the National Universities Commission (NUC) should consciously integrate the Student Industrial Work Experience Scheme (SIWES) into the business education curriculum content; and more so make it not just a sine qua non for graduation, but extend its duration to one year. This will avail the students a relatively longer period to interact with the reality in the industry in relation to the theory learned in the classroom. Consequently, employability skills will not be passively heard or acquired, but ingrained as a lifetime habits in the graduates.

\section{References}

1. Adebakin, A. B., Ajadi, O. T. \& Subair, S. T. (2015). Required and possessed universities graduate employability skills: perceptions of the Nigerian employers. World Journal of Education, 5(2), 115-121. Doi:10.5430/wje.v5n2p115

2. Ali, S. (2013). Factors affecting academic achievement of students. American Journal of Educational Research, 1 (8), 283-289

3. Anho, J. E. (2011). An Evaluation of the quality and employability of graduates of Nigerian universities. African Journal of social Sciences, 1(1), 179-182.

4. Aquah, P. A. (2014). Enriching the business education curriculum for relevance in the global workplace. Global Journal of Human - Social Science: G. Linguistic \& Education, 14(7), 31-35.

5. Arikewuyo, M. O. \& Ilusanya, G. (2014). Towards assuring quality in private universities in Nigeria. Journal of Educational Review, 7(4), 565-569.

6. Asuquo, A. E. \& Agboola, B. M. (2014). Nigerian universities outputs and their employability in the labour markets in south-south, Nigeria. American Journal of Educational Research, 2(12), 12441249, doi:10./12691/education-2-12-18

7. Australian Association of Graduates Employers (2001). 2011 AAGE Employer survey. Sydney, NSW, Australia: AAGE

8. Bamiro, O. A. (2012). Tertiary education in Nigeria and the challenge of corporate governance. Speech at the TETFund year 2012 strategic planning workshop held at the Idris Abubakar Auditorium, National Universities Commission, Maitaima, Abuja, $7^{\text {th }}$ to $8^{\text {th }}$ August, 2012

9. Bates, M. J. (2008). Preparing professionals for autonomy: workplace-based courses in professional education: UDN Dr. Muller
10. Bennett, T. M. (2006). Defining the importance of employability skills in career/ technical education. Dissertation project information and learning company

11. Billett, S. (2011). Learning in the circumstances of work: the didactics of practice. Education at didactique, 125-146. Doi:10.4000/educationdidactique. 1251

12. Business Dictionary (n.d.). Definition of work experience, www.businessdictionary.com.definition

13. Chillas, S., Marks, A., \& Gallowway, L. (2015). Learning to labour: An evaluation of internships and employability in the ICT sector. New Technology, work and employment, 30 (1), 1-15

14. Coll, R., Eames, R., Paku, L., Lay, M., Hodges, D., Bhat, R., Ram, S., Ayling, D., Fleming, J. Ferkins, L., Wiersma, C. \& Martin, A. (2009). An exploration of the pedagogies employed to integrate knowledge in work- integrated learning. Journal of Cooperative Education ND Internship, 43, (1), 1435

15. Confederation of British Industry (CBI), (2011). Building for growth: Business priorities for education and skills-education and skills survey 2011. London, United Kingdom: Author

16. Conference Board of Canada (CBC) (2000). Employability skills toolkits for the self -managing learner ( $1^{\text {st }}$ ed.) ISBN-10:0070878471, Pp. 10.

17. Council of Ontario University (2014). Bringing life to learning at Ontario University. Experiential learning report. Toronto: Council of Ontario University. Retrieved from http://.www.cou.on.ca/reports/bringing-life-to learning/

18. Daisi, K. (1997). Legal, Policy and Organizational Framework for the Campaign against examination malpractices and students' cults. A paper presented at the National Summit on the legal, policy and organizational framework, International Conference Centre, Abuja, 2-4 December.

19. Ekpenyong, L. E. (1988). Vocational content in the national curriculum for Nigerian secondary schools: How industry can help? The vocational aspect of education, 40(106), 57-62

20. Enahoro, J. A. \& Badmus, A. (2013). Emergence of private universities in Nigeria and monitoring standard between 2002 and 2012. American Journal of Business and Management, 2(1), 5964. Doi: $10.11634 / 216796061302258$.

21. Fapohunda, O. (2017, February 2017). List of accredited/approved universities in Nigeria (updated)

22. Federal Republic of Nigeria (2004). National Policy on Education (4 $4^{\text {th }}$ ed.) Lagos: NERDC

23. Folola, H. O., Ibidunni, A. S., Salau, O. P. \& Ojo, I. S. (2016). Skill management and universities 
competitiveness: An empirical evidence of Nigerian private universities. The Social Science, 11(6), 952-957.

24. Gault, J., Leach, E., \& Duey, M. (2010). Effects of business internships on job marketability: the employers' perspective. Education and Training, 52 (1), 76-88. Doi: 10.1108/00400911011017690

25. Ibrahim, H. \& Jaaffar, A. H. (2017). Employers' perspective on work-integrated learning: Evidence from Malaysian manufacturing and service companies. International Journal of Business Management, 2 (1),

26. Jackson, D. (2013). The contribution of work-integrated learning to undergraduate employability skill outcomes. Asia-pacific Journal of cooperative Education, 14 (2), 99-115

27. Jackson, D. (2016). Re-conceptualizing graduate employment: The importance of pre-professional identity. Higher Education Research and Development, 35(5), 925-939. Doi:10.1080/07294360.2016.1139551

28. Jackson, D., Ferns,S., Rowbottom, D. \& McLaren, D. (2015). Working together to achieve better work-integrated learning outcomes: improving productivity through better employer involvement. Retrieved from http://www.acen.edu.au/wp-content/upload/2016/06/working-toghther-to achievebetter-WIL-outcome.pdf

29. Jayanthi, S. U., Balakrishman, S. Ching, A.L. S., Latiff, N.A.A \& Nasirudeen, A. M. A. (2014). Factors contributing to academic performance of students in a tertiary institution in Singapore. American Journal of Educational Research, 2 (9), 752758. Doi:10.12691/education-2-9-8

30. Kathleen, C. (2005). Developing employability skills. Regional educational laboratory School Improvement Research Series (SIRS).

31. Kayode, M. O. (2002). Managing change in a $\mathrm{Ni}$ gerian university setting. Ibadan: University Press.

32. Khalid, N., Hamid, N. A.A., Salin, R., Othman, N., Awang, A. H. \& Nur, M.F.M. (2014). Importance of soft skills for industrial training program: Employers' perspective. Asian Journal of Social Science \& Humanities, 3 (4), 10-18

33. Marjahan, B., \& Newman, R. (2009). Evaluation of students' experiences of developing transferable skills and business using a business simulation game. Proceedings of the $39^{\text {th }}$ IEEE International Conference on Frontiers in Education Conference (FIE '09), ACM press, NJ, USA, 92-97

34. Martin, A. J., Rees, M. Edwards, M. Paku, L. (2012). An organization overview of pedagogical practice in work-integrated education. Asia-pacific Journal of Cooperative Education, 13 (1), 23-37
35. McCauley, C. \& Wakefield, M. (2006). Talent management in the $21^{\text {st }}$ century: Help your company find, develop and keep its strongest workers. Journal For Quality And Participation, 29 (4), 4-7

36. McConomy, S. (2010). Work experience and internship. University of Ulster

37. Mcllveen, P., Brooks, S., Lichtenberg, A., Smith, M., Torjul, P. \& Tyler, J. (2011). Career development learning frameworks for work-integrated learning in S. Billett \& A. Henderson (eds.), Developing learning professionals: integrating experiences in university and practice settings, 149-165. Dordrechti Springer.

38. Middlehurst, R. (2001). Quality assurance implications of new forms of higher education. European Network for Quality Assurance In Higher Education. Helsinki needs publisher.

39. Mike, U. (2014). Importance of skill acquisition: Dynamics of skill acquisition: A constraints-led approach.

40. Munishi, E. J. (2016). Factors contributing to lack of employability skills among technical and vocational education graduates in Tanzania. Business Education Journal, 1 (2),1-19

41. Munro, J. (2007). Fostering international referenced vocational knowledge: a challenge for the international circular. Journal of Research and International Education, 6, 67-93. Doi: 10.1177/1475240907024790

42. National Universities Commission (NUC) (2007). Benchmark Minimum Academic standards (BMAS) for undergraduate program in Nigerian universities, Abuja, Nigeria.

43. National Universities Commission NUC (2006). Webomatric Ranking of World Universities: Matters Arising. Monday Memo, NUC, Abuja, 5(11), 1-10.

44. Nwagwu, W.E. \& Agarin, O. (2008). Nigerian university websites: A webometric analysis. Retrieved from www.webology.org/2008/v5n4/a65.html

45. Okebukola, P. A. (2006, July 10). Intensive retraining program for graduate of universities for better quality and standard. A keynote address at the First Oyo State Education Summit, Ibadan

46. Oladipo, A; Adeosun, O. \& Oni, A. (2009). Quality assurance and sustainable university education in Nigeria. Retrieved from http://aadcice.hiroshimau.ac.jp/e/publication/sosho41-09.pdf.

47. Omar, M. K., Bakar, A. R. \& Mat-Rashid, A. (2012). Employability skills acquisition among Malaysian Community College Students. Journal of Social Sciences, $8(3)$, 472-478. http://dx.doi.org/10.3844/jssp.2012.472.478.

48. Orner, M.M. (2009). Employability skill acquisition of career and technical education students. $1^{\text {st }}$ 
Edn., Duqueswe University, ISBN:1109201214, 150

49. Paisey, C., \& Paisey, N. J. (2010). Developing skills via work placement in accounting: students and employer views. Account Forum, 34 (2), 89108. Doi:10.1016/j.accfor.2009.06.001

50. Rowe, A. D. \& Zegwaard, K. E. (2017). Developing graduate employability skills and attributes: curriculum enhancement through work- integrated learning. Asia-pacific Journal of Cooperative Education, special issue, 18 (2) 89-99

51. Sat, M.M., Yusoff, R. M., \& Panatik, S, A. (2014). The effect of industrial training on ethical awareness of final year students in a Malaysian public university. Asia-pacific Education Review, 15 (1), 115-125

52. Smith, C., Ferns, S., \& Russell, L. (2014). The impact of work-integrated learning on students readiness. Final Report. Sydney: office for learning and teaching, Australia. Retrieved from http://www.olt.gov.av/resource-impact-work-integrated-learning-student-work-readiness.

53. Smith, J., Meijer, G., \& Kielly-Coleman, N. (2010). Assurance of learning: the role of work-integrated learning and industry partners. In M. Campbell (Ed.), work-integrated learning: Responding to challenges, 409-419, Perth, WA: Australian Collaborative Education Network (ACEN)

54. Tony, O. A. (2014). The challenges of human resources development in Nigerian private universities. Journal of Business Management and Social Sciences Research, 3(2), 1-9.

55. Trede, F. (2012). Role of work-integrated learning in developing professionalism and professional identity. Asia-pacific journal of Cooperative Education, 13 (3), 159-167

56. Wikipedia free encyclopedia (2014). Definition of work experience. Retrieve d August 23 ${ }^{\text {rd }}, 2017$ 